\title{
Avaliação de desinfetantes químicos de uso doméstico contra Vibrio cholerae EL TOR (amostra não toxigênica)
}

\author{
Evaluation of the effect of chemical domestic disinfectants on Vibrio \\ cholerae EL TOR (non toxigenic strain)
}

\author{
Jorge Timenetsky *Roberto Mitio Yanaguita*, Luzinete Alves Silva*
}

\begin{abstract}
TIMENETSKY, J. et al. Avaliação de desinfetantes químicos de uso doméstico contra Vibrio cholerae EL TOR (amostra não toxigênica). Rev. Saúde públ., S. Paulo, 26: 328-31, 1992. As metodologias de avaliação microbiológica de desinfetantes são permanentemente questionadas porque os protocolos laboratoriais não representam as condiçōes reais de uso desses produtos. Em 1985, adotou-se no Brasil, a metodologia da Diluição-Uso da AOAC, para a qualificação microbiológica de desinfetantes químicos, para fins comerciais. Desta maneira, os desinfetantes domésticos são testados contra amostras padrões de Salmonella choleraesuis e Staphylococcus aureus. Pesquisou-se o emprego de Vibrio cholerae devido a sua atual importância, no Brasil, em termos de Saúde Pública, associada ao estudo da atividade antimicrobiana de desinfetantes. Dezenove produtos desinfetantes de uso doméstico encontrados no comércio foram microbiologicamente avaliados. A metodologia foi a Diluição-Uso com 10 carreadores. Os compostos ativos dos produtos incluíam: formaldeído, fenóis, cresóis, amônio quaternário, cloro e etanol, sendo que sete, eram de composição associada. Conforme as recomendações de uso, dezesseis produtos, devem ser utilizados sem diluição. Nestas condições, 9 desinfetantes foram vibriocidas e sete não revelaram tal atividade antibacteriana. Quatro produtos em diluiçōes não esclarecedoras para a desinfecção também mostraram-se ineficazes. Os produtos vibriocidas que devem ser utilizados sem diluição, foram reavaliados diluídos ao dobro. Estas soluçōes não inativaram V.cholerae, demonstrando microbiologicamente que os seus compostos ativos estão em concentraçōes limitrofes. $O$ álcool comercial $\left(95,5^{\circ} \mathrm{GL}\right)$ a $1: 3$, a "água sanitária" $(2,8 \%$ de cloro ativo) a $1: 200$, creolina a $1: 10$ e o "Lysoform" a 1:20 atingiram os padrões do teste.
\end{abstract}

Descritores: Desinfetantes. Vibrio cholerae. Avaliação microbiológica.

\section{Introdução}

As metodologias de avaliação microbiológica de desinfetantes são permanentemente questionadas porque a eficácia necessária de um composto ativo, nas condições reais de uso, são diferentes dos protocolos laboratoriais ${ }^{12,14}$.

A metodologia da Diluição-Uso padronizada pela AOAC ("Association of Official Analytical Chemist"), adotada no Brasil desde 1985 na qualificação de desinfetantes para fins comerciais ${ }^{1,8,11}$, preconiza a utilização de cepas bacterianas e/ou fúngicas padrões tidas como representativas. $\mathrm{Na}$ avaliação de desinfetantes domésticos utilizam-se Staphylococcus aureus e Salmonella choleraesuis. Para desinfetantes institucionais (banheiros públicos, clubes, escolas, colônias de férias) recomenda-se a inclusão de Pseudomonas aerugi-

\footnotetext{
* Departamento de Microbiologia do Instituto de Ciências Biomédicas da Universidade de São Paulo - São Paulo, SP - Brasil

Separatas/Reprints - J. Timenetsky - Av. Prof. Lineu Prestes, 1374-05508-900 São Paulo, SP-Brasil

Publicação financiada pela FAPESP - Processo Saúde Coletiva $91 / 4994-0$
}

nosa, enquanto que para os desinfetantes hospitalares, dependendo da área a ser descontaminada (não crítica, semi-crítica e crítica), além das espécies citadas, são incluidas espécies de micobactérias (M. smegmatis $e$ M. bovis) e esporos de Trichophyton mentagrophytes ${ }^{1,8}$.

Considerando que os desinfetantes quimi$\cos$ devam destruir microrganismos indesejáveis $^{4}$ e que $V$. cholerae não está incluído na qualificação de desinfetantes domésticos, o presente trabalho tem como objetivo verificar atividade vibriocida destes produtos comerciais através da metodologia da AOAC simplificada ${ }^{17}$.

Esta proposta vem ao encontro da crescente preocupação da Vigilância Sanitária, através de seu comunicado, no controle da cólera em nosso país no que se refere a utilizaçāo de outros desinfetantes ${ }^{6}$.

\section{Material e Método}

O microrganismo utilizado no teste foi a cepa de Vibrio cholerae EL TOR não toxigênica cedida pelo Instituto Adolfo Lutz de São Paulo. 
Os meios de cultura; manutenção, subcultivo e evidenciação presuntiva de $V$. cholerae foram:

Meio líquido ${ }^{1,8}$ - Caldo Nutriente (Difco) duas vezes concentrado com $0,5 \%$ de $\mathrm{NaCl}$. O $\mathrm{pH}$ final de 8,6 foi estabelecido para o subcultivo do víbrió.

Meio sólido ${ }^{1,8}$ - Meio líquido acima citado, adicionado com 1,4\% de Bacto-Agar.

Meio seletivo para víbrio - Agar TCBS, (tioglicolato citrato, bile e sacarose-Merck). Utilizado para evidenciação presuntiva do víbrio presente nos subcultivos positivos ${ }^{9}$.

Os produtos desinfetantes analisados: (Formulações transcritas dos rótulos dos produtos) foram:

- Álcool etílico $96^{\circ}$ GL (álcool comercial).

- Cloro ativo 2,8\% (água sanitária).

- Formol 0,74\% e N-Dodecilbenzenosulfonato de sódio $0,08 \%$ (Lysoform).

- Cloreto de alquil dimetil benzil amônio e cloreto de alquil dimetil etilbenzil amônio a $50,0 \%-1,6 \%$.

- Cloreto de alquil dimetil benzil amônio $0,25 \%$.

- Sal de amônio quaternário.

- Ortobenzil para clorofenol $0,1 \%$ (pinho sol).

- Cloreto de alquil dimetil benzil amônio $0,8 \%$, cloreto de alquil dimetil etilbenzil amônio $0,5 \%$.

- Éter 2,4,4' tricloro 2' hidroxifenílico $0,1 \%$.

- Formaldeído (solução de 0,3\%).

- Cresóis $4 \%$, fenol $0,4 \%$, benzol $1,6 \%$ (creolina).

- Ortofenilfenol $0,2 \%$

- Quaternário de amônio 50\% - 0,5\%.

- Alquilenoglicol monoaril éter $0,2 \%$.

- Quaternário de amônio $0,15 \%$ e formaldeído a $37 \%$ (solução $\mathrm{A} \quad 0,6 \%$ ).

- Cloreto de alquil dimetil benzil amônio $0,075 \%$, cloreto de alquil dimetil etil benzil amônio $0,075 \%$.

- Cloreto de alquil dimetil benzil amônio $0,05 \%$, cloreto de alquil dimetiletil benzil amônio $0,05 \%$, cloreto de alquil de trimetil amônio $0,05 \%$.

- Éter 2,4,4' tricloro - 2' hidroxifenílico $0,1 \%$ e formaldeído A $40,0 \%$ (solução A $0,2 \%$ ).

- Ortofenilfenol $0,3 \%$.

A metodologia de avaliação microbiólogica dos desinfetantes foi a simplificada da Di-
luição-Uso ${ }^{17}$ com 10 carreadores e $10 \mathrm{~min}$. de contato. Os produtos desinfetantes foram testados puros e diluídos $(1: 2,1: 3,1: 10,1: 20$, $1: 40,1: 50,1: 100,1: 200$ e $1: 400$ ), incluindo as diluiçōes designadas para a desinfecção, desodorização e/ou limpeza descritas nos rótulos.

\section{Resultados e Discussão}

Embora a qualificação microbiológica dos desinfetantes domésticos para fins comerciais seja realizada no Brasil com cepas de estafilococos e salmonelas, o $V$. cholerae assume atualmente, em termos de Saúde Pública, importância relevante no território nacional ${ }^{6}$.

O sorotipo EL TOR, sendo o vibrião mais resistente ${ }^{7}$, propicia a sua utilização como amostra representativa na avaliação de desinfetantes contra esses microrganismos. A utilização de amostra não toxigênica, oferece segurança nos procedimentos laboratoriais.

$O$ encontro de produtos desinfetantes ineficazes contra $V$. cholerae para superfícies fixas, mesmo quando não diluídos (produtos números $5,12,13,15,16,17$ e 18 - Tabela), além de revelarem as suas limitações na atividade germicida, prejudicam as orientações da vigilância sanitária na prevenção da cólera e outras doenças infecto-contagiosas, cujos agentes etiológicos são mais resistentes aos desinfetantes químicos ${ }^{13,15}$. Neste grupo de produtos, verifica-se que a maioria possui sais de amônio quaternário cujas formulações estão apresentadas de maneira não padronizada. Estes compostos são altamente sensíveis à matéria orgânica e passíveis de deterioração por bactérias contaminantes, merecendo portanto atenção especial ${ }^{17}$.

A indicação do preparo de diluições não claramente definidas para desinfecção, desodorização ou limpeza, descritas no rótulo dos produtos números $3,11,15$ e 19 , não revelaram atividade vibriocida diluídas a 1:80, 1:40, $1: 60$ e $1: 50$, respectivamente (Tabela).

Como as diluições arbitrárias são inevitáveis nesta categoria de produtos ${ }^{5,16}$, os desinfetantes podem transformar-se em soluções passiveis de perderem a atividade antimicrobiana desejada. Diluições ao dobro, da maiotia dos produtos vibriocidas, com recomendação de usá-los puros, não revelaram atividade antibacteriana no protocolo aplicado.

Portanto, evidencia-se microbiologicamente, que as concentrações dos compostos ativos, da maioria dos produtos, estão em 
Tabela. Atividade vibriocida de 19 desinfetantes quimicos de uso doméstico avaliados pela metodologia da Diluiçảo - Uso Simplificada (15).

\begin{tabular}{|c|c|c|c|c|c|c|c|c|c|c|}
\hline B $\quad A$ & Puro & $1: 2$ & $1: 3$ & $1: 10$ & $1: 20$ & $1: 40$ & $1: 50$ & $1: 100$ & $1: 200$ & $1: 400$ \\
\hline 1 & . & - & - & + & + & + & \# & $\#$ & $\#$ & $\#$ \\
\hline 2 & . & - & - & . & . & . & - & . & . & + \\
\hline 3 & . & - & . & . & . & + & + & + & + & $\#$ \\
\hline 4 & . & + & + & + & + & \# & \# & $\#$ & \# & \# \\
\hline 5 & + & + & + & + & \# & \# & \# & \# & $\#$ & $\#$ \\
\hline 6 & • & + & + & + & + & \# & \# & \# & \# & \# \\
\hline 7 & - & + & + & + & + & \# & \# & $\#$ & \# & $\#$ \\
\hline 8 & - & + & + & + & + & $\#$ & \# & $\#$ & \# & $\#$ \\
\hline 9 & - & + & + & + & + & \# & \# & \# & \# & $\#$ \\
\hline 10 & - & + & + & + & + & \# & \# & $\#$ & \# & \# \\
\hline 11 & - & - & - & - & + & + & + & + & + & + \\
\hline 12 & + & + & + & + & \# & \# & \# & \# & \# & \# \\
\hline 13 & + & + & + & + & \# & \# & \# & \# & \# & \# \\
\hline 14 & - & + & + & + & + & \# & \# & \# & \# & \# \\
\hline 15 & + & + & + & + & $\#$ & $\#$ & $\#$ & $\#$ & $\#$ & \# \\
\hline 16 & + & + & + & + & \# & \# & \# & \# & \# & \# \\
\hline 17 & + & + & + & + & \# & \# & \# & \# & \# & \# \\
\hline 18 & + & + & + & + & $\#$ & $\#$ & $\#$ & $\#$ & $\#$ & $\#$ \\
\hline 19 & - & + & + & + & + & \# & \# & \# & \# & $\#$ \\
\hline
\end{tabular}

\# Experimento nảo realizado porque o desinfetante foi ineficaz nas diluiçóes menores.

+ Recuperação de V. cholerae

Ausência de $V$. cholerae

$\bar{A}$. Diluição do produto desinfetante

B. Número do desinfetante testado

quantidades bactericidas limítrofes e, portanto, com pouca margem de segurança a um dos principais fatores interferentes, a diluição em água ${ }^{3}$.

A água sanitária atingiu os padrões do teste quando diluída em água a 1:200 a partir de sua embalagem. Portanto, as prováveis diluições arbitrárias deste e de outros produtos não avaliados, mas relacionados com esta propriedade, teriam menos chance de transformarem-se em soluções ineficazes em relação aos produtos que deveriam ser utilizados sem diluição.

Verificou-se em outra oportunidade que a metodologia da Diluição-Uso simplificada mostrou-se eficaz na triagem de desinfetantes $^{17}$. Os resíduos dos compostos ativos foram eluídos dos cilindros carteadores, através da lavagem em água, não interferindo portanto nos resultados.

A comprovação de $V$. cholerae nos subcultivos positivos foi caracterizada através do seu reisolamento, verificando-se o aspecto das colônias em ágar TCBS, prova da oxidase e as propriedades morfotintoriais (Coloração de Gram) do microrganismo recuperado ${ }^{2,9}$.
Convém salientar que os agentes químicos com atividade bactericida comprovada, utilizados para desinfecção, podem não atingir a concepção de desinfetante nas condições práticas de uso se as superfícies a serem descontaminadas não forem previamente lavadas com água e/ou sabão. As soluçōes germicidas devem ser entendidas como agentes complementares no contexto geral da desinfecção ${ }^{10}$.

Portanto, a utilização de outros desinfetantes, preconizada pela vigilância sanitária contra a cólera, deve ser entendida como um recurso adicional na prevenção desta doença.

TIMENETSKY, J. et al. [Evaluation of the effect of chemical domestic disinfectants on Vibrio cholerae EL TOR (non toxigenic strain)]. Rev. Saúde públ., S. Paulo, 26: 328-31, 1992 The methodology of microbiological evaluation of disinfectants is permanently being questioned because the laboratorial protocols do not correspond to the real conditions under which these products are used. In 1985 the Use-Dilution method of AOAC was adopted in Brazil for microbiological qualification of chemical disinfectants for commercial purposes. Domestic disinfectants are tested in this way against Salmonella choleraesuis and Staphylococcus aureus ATCC strains, was chosen for this evaluation 
Vibrio cholerae in view of its current importance in Brazil, in terms of Public Health associated with the study of the disinfectant's antimicrobial activities. Nineteen disinfectant products for domestic use for available to the public were evaluated microbiologically by means of simplified Use-Dilution test with 10 carriers. The active compounds of the products included formaldeyde, phenols, cresols, quaternary ammonium compouds, chlorine and ethanol. Seven were mixtures of these. According to the recommendations for their use, sixteen products should be used undiluted. Under these conditions, 9 disinfectants were vibriocides and 7 did not demonstrate this antibacterial activity. Four products in dilutions not clearly specificated were also ineffective. The vibriocide products which must used without dilution were tested again, diluted at 1:2. These solutions did not inactivate $V$. cholerae showing that, microbiologically, their active compounds are used in limited concentrations. Commercial alcohol $\left(95.5^{\circ} \mathrm{GL}\right)$ at $1: 3$, chlorine $2.8 \%$ Água sanitária at $1: 200$ and Lysoform at 1:20 came up to the standards required by the test.

Keywords: Disinfectants. Vibrio cholerae. Microbiological evaluation.

\section{Referências Bibliográficas}

\section{ASSOCLATION OF OFFICIAL ANALYTICAL} CHEMIST. Oficial methods of analysis. 14th ed., Artington, 1984.

2. BAUMAN. P. \& SCHUBERT, R.H.W. Family II. Vibrionacea. In: Bergey's manual of sistematic bacteriology. Baltimore, Williams \& Wilkins, 1984. v. 1. p. 516-38.

3. BEAN, H.S. Types and characteristics of disinfectants. J. appl. Bacteriol., 30: 6-16, 1967.

4. BLOCK, S.S. Definition terms. In: Block, S.S., ed. Desinfection sterilization and preservation. Philadelphia, Lea \& Febiger, 1983. p. 877-81.

5. BLOOMFIELD, S.F. The use of disinfectants in home: a review. J. appl. Bacteriol., 45: 1-38, 1978.

6. CENTRO DE VIGILÂNCIA SANITÁRIA. Comunicado CVS 1/91 e 2/91; prevenção da cólera. Diário Oficial do Estado de São Paulo. Seção I. 101 (87): 17,11 de maio 1991.
7. FESENFELD, $O$. The survival of cholera vibrios. In. Barua, D. \& Bunows, W. eds. Cholera. Philadelphia, W.B. Saunders Company, 1974. p. 359-66.

8. INSTITUTO NACIONAL DE CONTROLE DE QUALIDADE EM SAÚDE. Técnicas para controle de qualidade: avaliação da atividade antibacteriana de saneantes domissanitários. Rio de Janeiro, Fundação Oswaldo Cruz, 1985. [Manual Técnico n²].

9. MANUAL MEDIOS DE CULTIVO MERCK Agar TCBS (agar seletivo para Vibrio-Agar tiosulfato-citrato-sales biliares-saca rosa. E. Merck Frankfurter Strasse 250 D-6100 Darmstadt 1 (R.F. Allemania), 1982.

10. MAURER, I.M. Chemical disinfectantes: fiction and facts. In. Maurer, I.M. Hospital hygiene. 3rd. ed. London, Edward Amold, 1985. p. 59-74.

11. MINISTÉRIO DA SAÚDE Portaria $n^{2} 67$ de 21 de fevereiro de 1985. Diário Oficial da União, Brasília, 27 fev. 1985.

12. OLIVEIRA, M.S., Et al. Reflexões sobre a desinfecção hospitalar. Laes \& Haes 4 (4): 66-8, 1985.

13. ORGANIZAÇÃO PANAMERICANA DA SAÚDE. Profilaxia das doenças transmiss/veis. Washington, $11^{2}$ ed. Ed. Benenson, 1973.

14. REYBROUCK, $G$. The evaluation of the antimicrobial activity of disinfectants. In. Russel, A.D., eds, et al. Principles and practice of disinfection, preservation and sterilization. London, Blackwell, 1982. p. 134-57.

15. RUSSEL, A.D. et al. Guidelines on desinfection in animal husbrandry for prevention and control of zoonotic diseases. Washington, DC, World Health Organization, 1984.

16. SCOTT, E. \& BLOOMFIELD, S.F. Bacteriological investigation of effectiveness of cleaning and disinfection procedures for toilet hygiene. J. appl. Bacteriol., 59: 291-7, 1985.

17. TIMENETSKY, J. Avaliação microbiológica de desinfetantes químicos de uso doméstico. Rev. Saúde públ., S. Paulo, 24: 47-50, 1990. 